\title{
Language change and morphological processes
}

\author{
Camiel Hamans \\ University of Amsterdam \\ hamans@telfort.nI
}

\begin{abstract}
Morphological change is not a result of mechanical, predictable processes, but of the behavior of language users. Speakers reinterpret opaque data in order to assign a more transparent structure to them. Subsequently successful reinterpretation may form the basis of new derivations. The moment such a derivative word formation process becomes productive a language change has taken place.

In addition, this paper shows how language change obscures the distinction between separate morphological processes such as compounding and derivation and thus between morphological categories. Moreover, the data under discussion show that there is not a preferred natural direction of language change. Most of the examples are taken from English and Dutch, but also a few French, Frisian, German and Afrikaans data are discussed.
\end{abstract}

Keywords: language change; opacity; reinterpretation; bidirectionality; affixoid; libfix; state of transition.

\section{Introduction ${ }^{1}$}

This paper deals primarily with language change. It discusses how reinterpretation of opaque data may cause morphological change. In addition, it also demonstrates how language change blurs the distinction between separate morphological processes such as compounding and derivation and therefore also obscures the distinction between morphological categories. Finally, it shows that the arguments for a natural or preferred direction in language change are extremely weak.

Since the focus of this article is on language change, no position is taken in more theoretical morphological discussions, that have very little importance when it comes to language change.

\footnotetext{
${ }^{1}$ I want to thank the anonymous reviewers for their meticulous reading of an earlier draft of this paper and for their valuable suggestions for improvement.
} 
The paper consists of four parts, preceded by a preamble, in which the difference between affix and affixoid will be examined. The four parts are:

1. From part of compound to affixoid or affix, so change from less to more bound elements.

2. From affix or affixoid to free morpheme or lexeme, so change from more to less bound elements.

3. Libfixing, which is reinterpretation of opaque forms resulting in the "liberation" of elements.

4. Conclusion.

\section{Preamble}

Before we show how parts of compounds can change into affix or affixoid and vice versa, it may be useful to define what the difference is between affixes and affixoids (see also Bauer 2014: 121-122; Booij and Hüning 2014; Elsen 2011: 74-78). An example may clarify the difference.

(1) Dutch hoofd 'head'

(1a) compound

hoofdpijn

hoofdkantoor

hoofdinspecteur

(1b) affixoid

hoofdbezwaar

hoofdingang

hoofdartikel

(2) German Haupt- $\left({ }^{*}\right.$ Haupt $\left.^{2}\right)$

(2a) affix 'headache'

'head office'

'head inspector'

'main objection'

'main entrance'

'editorial/leading article'

\section{Hauptbahnhof \\ Haupteingang \\ Hauptattraktion}

\begin{abstract}
'Central Station'
'main entrance'

'major attraction'
\end{abstract}

\footnotetext{
${ }^{2}$ The German noun Haupt 'head' almost disappeared from the language. The current German word is Kopf. One still finds Haupt in an almost obsolete register, for instance in St. Matthews Passion (1727) by Bach (BWV244): O Haupt voll Blut und Wunden 'O Head full of Blood and Wounds'. In addition, the old lexeme can still be found as lexical base for a derivative such as enthaupten 'decapitate'.
} 
Etymologically the German and Dutch nouns Haupt and hoofd have the same origin. However, Haupt disappeared as a noun in German. ${ }^{3}$ Because of this, one makes a distinction between the Dutch affixoid hoofd-and the German counterpart Haupt-, which is defined as an affix.

The examples in (1a) show how the noun hoofd may combine with other nouns and then forms a compound. In hoofdpijn 'headache' the first part hoofd keeps its literal meaning. However, in the examples hoofdkantoor and hoofdinspecteur there is a small semantic change. The meaning is bleached from 'head' to 'top': a hoofdkantoor 'head office' or hoofdinspecteur 'head inspector' form the top of their organizations. Since a top is an upper part just as a head, hoofd, one may describe this new meaning in terms of a metaphor. However, this change is not due to the process of compounding. The Dutch noun hoofd acquired a secondary, metaphoric meaning already: upper part or upper position. The same applies to English head.

In (1b) hoofdbezwaar, hoofdingang and hoofdartikel the part hoofd- does not mean 'head', 'top' or 'upper part' but 'main', which shows that further semantic bleaching has occurred or in other terms that semantic demotivation has taken place.

In (2) Haupt-also lost its original meaning. However, Haupt- is called an affix, actually a prefix, since there no longer exists a corresponding noun in German. ${ }^{4}$

The difference between an affixoid and an affix is that an affixoid is an affix-like bound form, which corresponds to a free lexeme, whereas there is no

\footnotetext{
${ }^{3}$ This development is not restricted to German or to the noun Haupt. On the contrary, such a development is frequently attested: "First we find a particular word being used more and more frequently as a compound element, perhaps to the extent that its use as a compound element is more frequent than its use as an independent word. In some of these cases the meaning which is observed in the compound instances is also distinct from the meaning which pertains when the word is used independently" (Bauer 2004: 98). A next step may be the disappearance of this independent word. See for instance the English *monger, which still survives in words such as fishmonger and gossipmonger.

${ }^{4}$ In the recent German morphological literature, the term Konfix 'confix' has been suggested for parts such as Haupt (Donalies 2000, Donalies 2002: 21-23; Elsen 2005). A confix is a bound lexical morpheme, as in Stiefmutter 'stepmother' or Hauswart 'housekeeper', where the morphemes Stief- and -wart do not occur as autonomous lexemes in German. Also, neoclassical combining forms such as bio-, biblio- and -thek have been called confixes. However, neoclassical word formation is not the specific topic of this paper. Therefore, we do not discuss these cases here. In addition, since we are more interested in the topic of language change, in the change from Haupt to haupt- and in the corresponding change in Dutch, we prefer a terminology which shows immediately the relation ánd the difference between the two processes of language change. Therefore, we retain affix and affixoid.
} 
corresponding lexeme next to an affix. However, the difference between a free lexeme and the corresponding affixoid is that affixoids necessarily imply semantic change. An affixoid is a transitional in between noun ${ }^{5}$ and affix. Affixes and affixoids can both be used productively.

\section{From lexeme to affix(oid)}

The change from part of a compound to an affix or affixoid is well described in the history of the Germanic languages (see for instance Marchand 1969: 262264, 293; Bauer 2004; Elsen 2011: 85; Schmid 1998: 95-105).

Well known historical examples are given in (3).

$$
\begin{array}{ll}
\text { OE dōm 'jurisdiction, state' } & >\text { English saintdom } \\
\text { OE hād 'state, rank, character' } & >\text { English childhood } \\
\text { OHG heid/heit 'kind, appearance' } & >\text { German Flüssigkeit 'liquid' } \\
\text { PGm *līka- 'equal' from *līka- 'body' } & \text { Dutch lieflijk'sweet' } \\
& \text { German freundlich 'friendly' }
\end{array}
$$

Here, -dom, -hood, -keit, -lijk and -lich are suffixes, since there is no corresponding lexeme anymore. The forms not only lost their formal, lexical independence, but there also is a considerable semantic change. The original meaning is bleached almost entirely.

However, this process is not restricted to historical processes from remote periods. A well-known and widely discussed example is the Dutch case of -boer (Booij 2002: 152-153; Booij 2012: 87-88).

\footnotetext{
${ }^{5}$ Affixoids may also arise from other morphological categories. The German affixoids voll, arm, hoch and böse as in spannungsvoll 'full of suspense', fettarm 'low fat', hochmodern 'ultramodern' and bitterböse 'bitterly angry' correspond to adjectives, just as the Dutch vrij, vetvrij 'low fat' and oud, oud-minister 'former minister'. Verb-based affixoids are rare. However, in German one finds stinklangweilig 'deadly boring' and stinkwütend 'furious', originally from the verb stinken 'stink'. In Dutch one finds stikjaloers 'very jealous' from the verb stikken 'suffocate' and piepklein 'lilliputian' from the verb piepen 'beep'. In French, one comes across ample examples of affixoids with a prepositional and adverbial background such as sur 'on' and sous 'under' e.g. surchoix 'first class quality' and sousinformé 'badly informed' and bien 'well' versus mal 'wrong' such as in bienpensant 'right-minded' and malvoyant 'visually impaired'. For a comparison of Dutch and French affixoid see for instance Van Goethem (2008).
} 
(4) Dutch boer 'farmer'

$\begin{array}{lll}\text { (4a) } \begin{array}{ll}\text { wijnboer } \\ \text { groenteboer }\end{array} & \text { lit. wine farmer } & \text { 'wine grower' } \\ \text { melkboer } & \text { lit. milk farmer } & \text { 'greengrocer' } \\ & \text { 'milkman' }\end{array}$

(4b) krantenboer lit. newspaper farmer 'newspapers vendor' lesboer lit. lesson farmer 'nine-to-five-teacher'

In the examples in (4b), -boer constitutes an affixoid, because of the existence of a corresponding noun boer and of the bleached meaning.

Here, the semantic change can be followed step by step. In wijnboer, boerstill refers to a farmer, in the two following examples the referent may be a farmer who also hawks his products on the street. Later, groenteboer and melkboer could refer to people who did not produce their greens or milk, but only sold these products on the street, on a market or in their shops. The sales aspect became dominant in the meaning of these two compounds. In krantenboer the sales aspect is the only semantic feature that is left. ${ }^{6}$ Finally, a lesboer may be considered someone who routinely but 'sells' his lessons in an uninspired manner. Here not only is nothing of the original agricultural meaning left, but even the sales aspect is no longer dominant. Therefore, in (4b) -boer will be called an affixoid.

This process of compounds that lead to affixoids is a very frequent and productive process as the following examples from modern Dutch, German and Afrikaans will show. The next two examples (5) and (6) come from Dutch and show how a compound member may become a prefixoid. In (7) and (8) similar German examples are given, presenting a suffixoid in (7) and a prefixoid in (8). Finally, an Afrikaans prefixoid will be presented in (9).

$$
\text { Dutch poep- 'shit' }
$$

$\begin{array}{ll}\text { poepdoos } & \text { lit. poo box } \\ \text { poepchinees } & \text { lit. poop Chinese } \\ \text { poep(ie)sjiek } & \text { lit. poo chic } \\ \text { poepiedik } & \text { lit. poo fat }\end{array}$

'shit house'
'invective for Chinese people'
DIM 'very chic'
DIM 'very fat'

\footnotetext{
${ }^{6}$ However, an editor or a publisher of a newspaper may jokingly call himself een krantenboer.
} 
(6) Dutch pracht- 'splendor'

(6a) prachtuitgave lit. splendor edition

'deluxe 'edition'

prachtkleed

lit. splendor gown 'breeding plumage'

prachtmeid

lit. splendor girl 'wonderful girl'

prachtwijk

lit. splendor district

'power district'

(7) German -papst 'pope'

(7a) Skipapst

lit. ski pope

lit. swim pope

Kunstpapst

lit. art pope

Literaturpapst 'ski pope/skiing pope'

'leader in the swimming world' 'art pundit'

'literary guru'

(8) German Mord- 'murder'

(8a)

Mordsgeschrei
Mordsangst
Mordsding
Mordshunger

lit. murder cries

lit. murder fear

'great outcry'

'mortal fear'

lit. murder thing

'bloody/gigantic thing'

lit. murder hunger

'great hunger'

(9) Afrikaans hond- 'dog'

(9a)

hondsziek
hondstrouw
hondmak
hondsnaaks

lit. dog sick

lit. dog faithful

'sick as a dog'

'devoted'

'very docile'

hondsnaaks

lit. dog docile

lit. dog funny

'very funny'

In (5), (8) and (9) semantic demotivation may go so far that only an intensifying meaning remains in the end.

The process illustrated here in the examples (4-9) is usually called grammaticalization (Hopper and Traugott 1993), since it is a change from a less to a more bound element. However, Lehmann (1989) considers it to be an instance of lexicalization, since derivational affixes are not indicators of grammatical functions. They are morphemes than can be used in processes of word formation. However, one may call the intensification function these bound elements have a grammatical function. Booij and Hüning (2014) describe the pro- 
cess as an instance of constructionalization. Since we are not discussing construction grammar here, we only mention their label.

Whatever label is assigned to this process; it is clear a process of language change in which a free lexeme becomes a bound morpheme. The examples also show that the change is a gradual process, in which one cannot clearly distinguish between compound and derived form and so between the different morphological categories of noun and affixoid.

\section{From affix(oid) to free morpheme or lexeme}

A change in the opposite direction, so from a bound to a less bound morpheme or even to a new lexeme, is also possible and has been documented several times recently.

An example, that has been discussed before, is the change from Dutch -tig or German -zig or Frisian -tich to a numeral and subsequently to an adverb (Hamans 1993; Norde 2006; Norde and Van Goethem 2015).

$$
\text { Dutch -tig }
$$

$$
\begin{aligned}
& \text { twintig 'twenty' } \\
& \text { dertig 'thirty' } \\
& \text { veertig 'forty' }
\end{aligned}
$$

(10c) tig fietsen 'many bicycles'

(10d) tig veel 'very much'

Here the change is evident. In (10c) tig is a free lexeme, a numeral, with a rather vague meaning; 'many'. In (10d) tig functions as an intensifying adverb. ${ }^{7}$

The question here is whether -tig is a real suffix. In vijftig, zestig and zeventig it clearly is, since the base words after which the suffixes follow are vijf

\footnotetext{
${ }^{7}$ One may feel inclined to call the change from affix to noun discussed here and the following changes from affixoid to lexeme and vice versa instances of conversion. However, this would require a much broader definition of conversion than is usual. Conversion is usually described as a process that changes the word class of lexemes, so from one word class into another with no concomitant change in form, but not of bound elements and in any case never of a non-morphemic part of a word. (Bauer et al. 2013: 27 and ch.25). In addition, conversion is an abrupt process whereas the processes under discussion are gradual (cf. Van Goethem and De Smet 2014: 253).
} 
'five', zes 'six' and zeven 'seven'. However, there are no such numerals in Dutch as *twin, *der and *veer. The existing corresponding numerals are twee 'two', drie 'three' and vier 'four'. The same applies to German zwanzig 'twenty' and Frisian tweintich, tritich and fjirtich. The corresponding numerals in German and Frisian are zwei and twa, trije and fjouwer respectively. ${ }^{8}$

Examples that start with an affixoid show a clear pattern.

(11) Dutch kut- 'cunt' (Norde and Van Goethem 2015)

\begin{tabular}{|c|c|c|c|}
\hline (11a) & kutkaas & lit. cunt cheese & 'sperm' \\
\hline & kutpooier & lit. cunt pimp & ‘pimp’ \\
\hline & kutsmoes & lit. cunt pretext & 'shitty excuse' \\
\hline & kutmarokkaan & lit. cunt Moroccan & 'invective for Dutch Moroccans' \\
\hline
\end{tabular}

Most likely kutkaas is a compound of kut 'cunt' and kaas 'cheese', whereas in kutsmoes and kutmarokkaan kut is an affixoid with an intensifying negative meaning. The noun smoes 'pretext' itself has already a clearly negative meaning. Possibly Marokkaan too, at least in this context, ${ }^{9}$ however in forms such as kutmuziek or kutweer 'lousy music' and 'very bad weather' it is not the noun muziek or weer that have a negative meaning. The negative meaning is caused here by the intensifying negative prefixoid kut-.

This affixoid may change into an adjective or adverb. As an adjective, it may be used predicative as well as attributive.

(11b) Dit is kut. 'This sucks.'

Ik voel me kut. 'I feel like shit.'

(11c) ?een kutte vakantie 'a shitty holiday' de kutste loting 'the shittiest drawing of lots'

(11d) Mijn Volkswagen Polo reageert kut op het gas.

'My Volkswagen Polo reacts badly when I accelerate.'

\footnotetext{
${ }^{8}$ One may consider *twin-, *der-, *veer etc. as allomorphs of twee, drie and vier. In that case there will be no discussion about the suffix status of -tig.

${ }^{9}$ It was the Dutch social democratic politician Rob Oudkerk who introduced this term of abuse as a form of address in 2002, while speaking about the negative aspects of the behavior of young male Dutch-Moroccans in Amsterdam.
} 
Another example, also discussed by Norde and Van Goethem (2015) is (12).

(12) Dutch reus/reuze- 'giant'

(12a) reuzegroot lit. giant big 'enormously big' reuzeleuk lit. giant funny 'very funny'

In (12a) reuze, which comes from a noun reus, is an intensifying affixoid. In $(12 b)$ it is a free lexeme, adjective or adverb, meaning 'great'.

(12b) Dit is reuze. 'This is amazing.' Ik voel me reuze. 'I feel great.' een reuze meid 'a great girl'

(12c) Dat klinkt reuze nobel. 'That sounds very noble.'

This type of change is not restricted to Dutch. A few examples from German will do to illustrate this.

(13) Hammerfrau 'power lady'

Bombenjob 'plum job'

Spitzenfrau 'top woman, gorgeous woman'

Klassefrau 'wonderful (female) person'

(14) Das ist hammer. 'This is incredible.'

Das ist bombe. 'This is awesome.'

Das ist spitze. 'This is top.'

Das ist klasse. 'This is smashing.'

Careful analysis of these and other examples leads to a preliminary conclusion:

- Usually it is an affixoid not an affix that can 'emancipate" ${ }^{10}$ to become an adjective or adverb. ${ }^{11}$

\footnotetext{
${ }^{10}$ The terms emancipation and emancipate are introduced by Norde en Van Goethem (2015) to describe this process of language change.

${ }^{11}$ However, in German incidentally also a particle such as $z u$, as in zumachen 'to close' may be used as an adjective eine zu(n)e Tür 'a closed door'. In the dialects of the Dutch province Limburg
} 
- The emancipation follows after a process of affix(oid) formation, which is a change from member of a compound to an affix(oid). This suggests that this change is due to the still existing correspondence and bond with the original free lexeme.

- However, the new free lexemes belong to a different morphological category and acquire a new meaning.

- The process of emancipation also seems to be a gradual process of morphological change.

\section{Libfixing or the liberation ${ }^{12}$ of elements}

So far, we discussed processes in which free or bound morphemes played a role. The third process which will be examined now is a language change in which elements without any morphological status, not even that of morphemes, will be reinterpreted as having a certain morphological status.

The change that will be discussed here is a form of reinterpretation of opaque forms as if they were transparently analyzable (grammatical) syntagmas ${ }^{13}$ (Marchand 1969: 2) followed by a subsequent liberation of elements. ${ }^{14}$

The result of such a process is called a libfix by Zwicky $(2010)^{15}$. On a scale of bondedness such a change may be described as a change from more to less bound.

\footnotetext{
one comes across the same phenomenon: eine toee deur 'a closed door' next to the verb toemaken 'to close'. As the glosses show, there is no difference in meaning between the particle and the noun, whereas in the other examples under discussion always a semantic change takes place. In addition, prefixes such as super- and mega-, as in Superfrau and Megafrau, also emancipate to become an adjective: Das ist wirklich super/mega 'this really great'. However, super-, mega- etc. are part of a special category of neoclassical shortenings that subsequently may become affixes. This type of neoclassical word formation will not be discussed further here.

${ }^{12}$ The term liberation has been introduced in this context by Zwicky (2010), just as the neologism libfix.

${ }^{13}$ According to Marchand (1969: 2) a grammatical syntagma is a combination of full linguistic signs formed by compounding, prefixation, suffixation, derivation by a zero morpheme or back derivation.

${ }^{14}$ This process of reinterpretation and subsequent productive use of marginal material with a different morphological function resembles exaptation. According to Lass (1990: 80) “exaptation [...] is the opportunistic co-optation of a feature whose origin is unrelated or only marginally related to its later use". However, the material Lass discusses is so called "junk", linguistic material which lost its function during the history. The opaque forms under discussion here have no original morphological function whatsoever.
} 
Traditionally one uses the term splinter for such non-morphemic portions of a word that has been split off (Adams 1973: 142, 149; Bauer et al. 2013: 19, 525; Lehrer 1996: 361; Mattiello 2013: 258; Mattiello 2017: 8,16,71-72; for Dutch, Meesters (2002) and Van den Toorn 1983). Since the term splinter focuses on the result of the process of splitting and not on the potential of the remaining portion, we prefer the new term libfix, in which its allusion on affix emphasizes the possible productive word formation aspect, that will be shown hereafter. In addition, the term splinter quite often is defined as "parts of words in blends which are intended to be recognized as belonging to a target word, but which are not independent formatives" (Lehrer 1996: 361). ${ }^{16}$ As we will see also splinters of opaque, non-blend, forms may become a recurrent element in a series of new formations, which is another reason to prefer the new term libfix.

A first example from Marchand (1969: 211) will show how libfixing may work.

\section{(15) English scape}

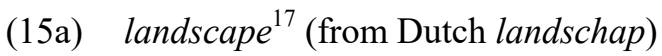

(15b) seascape

mindscape

moonscape

(15c) soundscape

dreamscape

memoryscape $^{18}$

\footnotetext{
${ }^{15}$ Jespersen (1928: 384) already describes "the phenomenon that one portion of an indivisible word comes to acquire a grammatical signification which it had not at first, and then is felt as something added to the word itself". Jespersen also uses the term secretion for a similar process in first language acquisition by children. Since we here discuss examples that show no relation with native language acquisition, we prefer a different term.

${ }^{16}$ For Adams (1973: 142) there is direct relation between splinters and blends: "Words containing splinters I shall call blends."

${ }^{17}$ First in use as a term for a painting representing an extensive view of natural scenery. Later, landscape acquired a non-artistic meaning. In Dutch landschap originally meant scenery. The meaning 'painting representing a scenery' followed later.

${ }^{18}$ The last two examples are taken from Bauer et al. 2013: 527). Whether these two last forms are more than occasionalisms is hard to say. However, soundscape is already widely accepted. For the difference between neologisms and occasionalisms see Mattiello (2017: 25): neologisms form a
} 
Landscape is an opaque form, in which the speakers of English recognize an existing word land. ${ }^{19}$ Subsequent reinterpretation then leads to an analysis as if landscape is a compound. So *scape must be attributed a certain morphological status, which makes it possible to use it productively as in (15b). The recent coinings soundscape, dreamscape and memoryscape show that the process is still productive.

Since *scape does not have a clear morphological status of its own, one may call it a libfix following Zwicky (2010); in this case more precisely a postlibfix.

It is not necessary that the language speaker recognizes an existing word in the opaque form, as another example, also adapted from Marchand (1969: 212213), will show.

\section{(16) English cavalcade}

\section{(16a) autocade aquacade motorcade camelcade}

"The word cavalcade was re-interpreted as containing the element caval'horse' and the suffix -cade "parade" (Marchand 1969: 212).

Another similar example offers forms derived from the English forms $\mathrm{Wa}$ tergate and hamburger.

$$
\begin{aligned}
& \text { closetgate } \\
& \text { nipplegate } \\
& \text { donutgate }
\end{aligned}
$$

(18) hamburger

(18a) fishburger
cheeseburger
weedburger

\footnotetext{
stable lexical enrichment of the language, whereas occasionalisms usually have a mere stylistic or more provisional value.

${ }^{19}$ See for this process of recognition of existing or similar forms, a so called confusivum, Zabrocky $(1969,1980)$ or Hamans $(1988)$. Recognition of existing or similar forms also form the basis for folk etymology (Hamans 1993). As we will see below (note 21) there is a difference between classical folk etymology and libfixing. In addition, we agree with Bauer (2003: 162) that "the label is not particularly enlightening".
} 
Originally Watergate was a compound, but in the meaning discussed here it was only a name, without any transparent morphological structure. However, since the original form is a grammatical syntagma, speakers of the language distinguished two separate elements water-and -gate of which the last one became used in a word formation process productively. Since the meaning of -gate in this process has no relation whatsoever with the original meaning one cannot describe this process either as a form of (quasi) compounding or as a process of affixoidation. ${ }^{20}$ Therefore, an analysis in terms of libfixing seems more adequate.

The hamburger-case may be analyzed in a similar way. Speakers reinterpret hamburger as a quasi-compound, consisting of ham and burger, which resulted in a productive process of -burger derivation. ${ }^{21}$

Another example which shows a similar pattern is the English word advertising, in which speakers most likely recognize the existing clipped form $a d$ for advertisement and which consequently leads to the 'liberation' of the libfix vertising.

$$
\text { advertising }
$$

$$
\begin{aligned}
& \text { webvertsing } \\
& \text { trashvertising }^{22}
\end{aligned}
$$

However, sometimes speakers do not recognize an existing form, but a similar form only, as in the following list of -istan examples. ${ }^{23}$

\footnotetext{
${ }^{20}$ In case -gate should be described as an affixoid, then one might have expected at least a minimal, bleached aspect of the original meaning to have remained.

${ }^{21}$ Some of these cases have been discussed as instances of folk etymology (cf. Maiden 2008 for a discussion). However, we would like to restrict the label folk etymology to examples where reinterpretation also results in a change of the wordform as in crayfish from the Old French crevice 'crab', cf. Modern French écrevisse. However, what the libfix cases discussed here and folk etymology have in common is that both result from reinterpretation of opaque forms, plus that in both cases there is no clear semantic relation between the input and the output of each process.

${ }^{22}$ Promotional text seen on an Amsterdam garbage truck. However, the Urban Dictionary describes trashvertising as "The act of advertising by leaving printed promotional materials where someone will have remove it and/or throw it away to go about their daily business. Fliers on door handles, fliers on car windshields, 'sample' newspapers in the driveway. These items often end up in the parking lot, street, etc. as people typically just throw them somewhere to get them out of the way" (http://nl.urbandictionary.com/define.php?term=trashvertising).
} 
(20) Pakistan

Afghanistan

Kurdistan

Uzbekistan

Recognition of a similar element -istan, ${ }^{24}$ in the terms of Zabrocki (1969) a confusivum, makes the speaker of the language think that these examples consist of two parts $\mathrm{X}+$-istan. Again, this may lead to a productive process of word formation, in which the libfix -istan takes part.

(20a) Londonistan

divorcistan

dum(b)fuckistan

cut off istan

A similar example from Dutch even leads to a free lexeme (Hamans 1993).
secretaris 'secretary'
notaris 'notary'
mandataris 'mandatory'
legataris 'legatee'

(21a) taris $(\mathrm{N})$ 'officer of the naval administration'

Also, blends may be used as a starting point for libfixing, as the following forms show.

\footnotetext{
${ }^{23}$ Linguists may know that -(i)stan originally is a Classical Persian suffix, meaning 'the land of' (Maciuszak 2008), that is derived from a similar noun stāna- 'land', via the righthand part of a nominal compound (cf. English, German and Dutch -land). However, the speakers of English who coined the words in (20a) most likely were not linguists, but ordinary speakers of English without any knowledge of Farsi.

In Dutch, one comes across similar new formations such as Verweggistan 'Far away land' and Boerenpummelistan 'Yokels country'. The knowledge of Farsi among ordinary speakers of Dutch is negligible, just as among native speakers of English. Therefore, it is very unlikely that the reinterpretation of the forms under (20) goes back to a historical Persian suffix.

${ }^{24}$ Or -stan as resulting in homostan or refugeestan.
} 
(22) English -(a)thon

(22a) marathon

(22c) telethon (blend from television + marathon $^{25}$ )

(22d) swimathon

readathon

walkathon

danceathon

Here again, speakers reinterpret the possible first blend telethon as a grammatical syntagma, in which one can distinguish a segment -athon. Because-athon is neither a free lexeme nor an affix(oid), one should call it a libfix. Here some of the original meaning is retained: 'taking a long time'.

Reinterpretation of a blend followed by liberation of a libfix even can result in a free lexeme, as the next example shows.

(23) English -zine

(23a) magazine

(23b) femzine (blend from feminist + (maga)zine)

perzine (blend from personal + (maga)zine)

(23c) fanzine

e-zine

(23d) zine $\mathrm{N}$

The change which took place here may have started with a blending process, such as in (23b). The next step then must have been liberation of -zine which resulted in new formations, such as the ones in (23c). Finally, zine emancipated and turned into a noun, to use the term Norde and Van Goethem (2015) introduced to describe similar processes. The fact that the emancipation here ends in

\footnotetext{
${ }^{25}$ The form telethon can also be analyzed as clipped compound consisting of tele + (mar)athon. However, this does not make any difference for the word formation process that follows. See for a definition of clipped compounds note 27 .
} 
a noun, ${ }^{26}$ whereas the emancipation processes described by Norde and Van Goethem (2015) result in adjectives or adverbs, may be a consequence of the fact that the segments described here are the righthand parts of the original forms. These original opaque forms were nouns, so intuitively the righthand part is seen as the head of this quasi-"composite" by the language speaker. In the examples discussed by Norde and van Goethem it is the lefthand part, so a determinator, which receives new status.

A final example, already discussed briefly in Hamans et al. (2009) and Hamans (2010) may show once more how this process of libfixing and subsequent total liberation or emancipation works.

The example starts with the English word entertainment, in which the language speaker recognizes an existing word enter. Therefore, he reinterprets this opaque form as if it was a transparent quasi-compound.

$$
\text { entertainment } \rightarrow \text { enter- }+ \text {-tainment }
$$

A next step may be blending or clipped compounding, ${ }^{27}$ leading to forms such as the ones in (24a).

$$
\begin{aligned}
& \text { infotainment }(\text { from info(rmation })+(\text { enter }) \text { tainment }) \\
& \text { docutainment }(\text { from docu(mentary) }+(\text { enter }) \text { tainment }) \\
& \text { relitainment }(\text { from reli(gion/gious })+(\text { enter }) \text { tainment })
\end{aligned}
$$

\footnotetext{
${ }^{26}$ Just as in (21a) taris.

${ }^{27}$ A clipped compound is a compound consisting of two clipped nouns, as in infobus 'a mobile unit where asylum seekers can get information and support' found in Cyprus. Infobus is a compound of the clipped nouns info(rmation) and (auto)bus. Clipped compounds should not be confused with stub compounds. A stub compound is a compound consisting of clipped parts (cf. Mattiello 2013: 77) not of independent, clipped nouns. Examples of stub compounds are conlang from constructed language or slomo from slow motion. In addition, stub compounds should not be confused with blends, also called portmanteau words. Blends follow the original stress pattern of the second (right-hand) source word, whereas stub compounds are compounds and therefore have stress on the first member. In addition, blends usually consist of a left-hand part of the first source word and a righthand part of the second source word. So, $\mathrm{AB}+\mathrm{CD} \rightarrow \mathrm{AD}$ (Plag 2003: 123). Stub compounds consist of the first, utmost left parts of both source words: AC (Bauer et al. 2013: 458; Hamans, submitted).

In case one wants to describe the forms in (22c) and (24a) as a result of clipped compounding, one has to accept athon and tainment as an already existing free forms, which is a matter for discussion; see note 29.
} 
A following step may be a productive derivative word formation process making use of the new libfix -tainment.

(24b) wintertainment

summertainment

slumbertainment ${ }^{28}$

A final step in this development is the total liberation or emancipation of tainment, ${ }^{29}$ as in (25).

\author{
adult horror tainment ${ }^{30}$ \\ Barack tainment ${ }^{31}$
}

In Dutch, where forms such as infotainment, docutainment, wintertainment have been borrowed from English and where the loanword entertainment is a frequently used word, the change even goes one step further.

Dutch examples as the ones in (25a) show a stress shift, from -táinment to the first part.

\footnotetext{
${ }^{28}$ One may also describe the word formation process which results in these forms as a blending process. However, this requires a recurring incidental blending process, which denies the productive character of this kind of word formation. That is why the process here is described as a derivative word formation process. In addition, forms as the ones given hereunder in (24c) can be described as a result of blending. However, whereas one of the characteristics of blending is that the resulting form fits almost perfectly into the syllabic and prosodic patterns of the second source word - here entertainment - there are good reasons not to analyze the forms in (24c) and by extension the ones in (24b) as a result of blending, but as a product of a derivative word formation process (Hamans 2014; Hamans, forthc.). The forms in (24c) show a monosyllabic first part, whereas the first part of entertainment is disyllabic.
}

(24c) sportstainment

skitainment

sextainment

${ }^{29}$ Whether the examples of (25) should be considered as the first instances of a neologism tainment in English or as occasional formations, is still unclear. However, even when the attested forms only have an incidental character, this has no effect on the argument. Whatever the status of the resulting form tainment is, the change under discussion is a change from a most bound element to a possibly free form.

${ }^{30}$ Title of a chapter of a novel by Tecori Sheldon (2012) When Truth is Gangsta: A Novel. New York/London/Toronto/Sidney: Strebor Books.

31 "The Barack Obama Song. That's Barack tainment" (22MOON.Com). Available online at https://rashmanly.com/2010/03/23/barack-obama-song-book/. 
(25b) Twéntertainment 'tainment in the region of Twente'

Gááspertainment 'tainment at the Gaasperplas (a lake)'

Limburgertainment 'tainment in the province of Limburg'

The examples under (25b) show compound stress, which suggests that tainment should be described as a noun here, which is corroborated by the examples in $(25 \mathrm{c})$ and $(25 \mathrm{~d})$.

(25c) John de Mol is de grootste producent van tainment. 'John de Mol is the largest producer of tainment.'

(25d) Tainment neemt de plaats in van serieuze programma's. 'Tainment is taking over the place of serious programs.'

An additional argument not to analyze a form such as Limburgertainment as a blend, is the number of syllables of the first part. Most blends copy the syllabic and prosodic structure of the second source word (cf. Hamans, forthc.). Here entertainment. The first part of Limburgertainment consists of three syllables where the model entertainment only accepts two. For compounds, there is not such a restriction on the number of syllables of the first part.

So far, we have seen libfixing as a result of reinterpretation of opaque forms. Four different types of opaque forms, which may be the starting point of a process of liberation, are discussed:

- quasi compounded loanwords, ${ }^{32}$ such as English landscape and cavalcade;

- quasi compounds, such as English hamburger and bootlegger,;

- blends, such as English telethon;

- a list, series or paradigm of similar forms such as Dutch secretaries.

The observations presented here bring us to the conclusion that reinterpretation of opaque forms often leads to a process of segmentation and consequently to "liberation" of forms which until then were inseparable parts of the complex opaque form and were parts without any linguistic status, neither free nor

\footnotetext{
32 These loanwords may be a compound in the language of origin, such as Dutch landschap. However, this is not necessary as cavalcade from Italian cavalcata shows.

${ }^{33}$ Bootlegger resulted in foodlegger, booklegger, meatlegger, tirelegger (Marchand 1969: 211). These words never became frequent or popular and disappeared when these products were no longer rationed in the U.S.
} 
bound. ${ }^{34}$ Although the original elements have no morphological status whatsoever this change may be described as a change from more bound to less bound, since inseparable parts might be described as maximally bound.

Reinterpretation of opaque forms may lead to new morphological segments, here called libfixes, ${ }^{35}$ that find their origin in elements that had no morphological status so far. Subsequently these bound morphemes may take part in productive (paradigmatic) word formation processes in a way similar to that of an affix(oid).

Incidentally, libfixes may then fully emancipate to become free lexemes in a way similar to that of affixoids. However, in contrast to the emancipatory result of affixoids, the final stage of an emancipated libfix is that of a noun, which can be explained because of the righthand and thus quasi-head character of the original element in the opaque structure.

\section{Conclusion}

So far three processes have been described:

(a) Nominal part of a compound $\rightarrow$ affix(oid); for instance, (4b) lesboer.

(b) Affix(oid) $\rightarrow$ adjective/adverb; for instance, (11b) dit is kut. ${ }^{36}$

(c) Non-morphemic part of an indivisible, opaque $\mathrm{N} \rightarrow$ libfix $\rightarrow \mathrm{N}$; for instance, (23d) zine.

In (a), the direction of the change is from free to bound morpheme.

In (b), the direction of the change is just the other way around: from bound to free morpheme.

\footnotetext{
${ }^{34}$ As said before, reinterpretation of opaque forms also is the basis for folk etymology. However, in folk etymology libfixing is not a requirement.

${ }^{35}$ Warren (1990) calls segments such as -(or)nography from pornography and found in for instance warnography combining forms. Olsen (2014:34-36) uses the term neoclassical combining forms. Zwicky (2010) prefers his label libfix instead of combining form, since "“combining forms' include both liberated elements and elements from complex learned forms, as in thermometer. It would be nice to have a term for the liberated elements that is both more memorable than 'combining forms' and also signals the origin of these elements in the reanalysis of existing words (whether the source words are ordinary words (...), or portmanteaus (...)". As will be clear, we agree with Zwicky.

${ }^{36}$ Process (a) is also involved in process (b), as we have seen in examples (11a) and (12a).
} 
In (c), the direction is from an inseparable, so maximally bound part, via a less bound segment to a free morpheme.

The processes of language change that are discussed here are gradual, as has been shown. Since these processes go from compounding to derivation and vice versa the distinction between these morphological processes becomes less clear and absolute than the handbooks suggest. As a consequence, the same applies to the distinction between morphological categories.

Finally, the morphological changes described and analyzed here show that there is not a natural or naturally preferred direction of change in the languages under discussion. Maybe the number of changes in one direction (from free to bound morphemes) are higher than in the other, as often claimed, ${ }^{37}$ but frequency is an extremely weak argument for a supposed natural direction. The results of the language changes discussed here may refute suggestions of unidirectionality, as defended within grammaticalization theory (see for instance Haspelmath 2004).

Reinterpretation by the language speaker is shown to be essential in the processes of language change, discussed here. By means of this process of reinterpretation the language speaker recognizes an existing but not related form within a hitherto opaque form or a frequently recurrent part in a paradigm of opaque forms. This is what Zabrocki (1969) calls a confusivum.

Subsequently the language speaker grants a morphological status to this "recognized" part. The next step may be that this part functions as the starting point of a new productive process of word formation.

What follows from what has been said so far is that there are no blind forces operating in these processes of language change (cf. Schuchardt 1922). The idea of an invisible hand that operates in language change and which shows the direction of change should thus be rejected (Booij 2012: $262^{38}$ ). It is much more plausible that the language system constantly is in a state of transition because of a continuous process of reinterpretation by the language speakers, as Schuchardt (1922) claims. It is the (re)interpretation of the language speaker that starts the change and determines the direction of this change.

\footnotetext{
${ }^{37}$ For instance, by Heine, Claudi and Hünnemeyer (1991: 4) and Ramat (2001: 396).

${ }^{38}$ Booij's reference of the invisible hand theory of Adam Smith may be an echo from Keller (1994), although Keller's invisible hand theory only explains language change retrospectively. See for comments on Keller's invisible hand theory Hüning 1993: 294-298).
} 


\section{References}

Adams, V. 1973. An introduction to Modern English word-formation. London: Longman.

Bauer, L. 2003. Introducing linguistic morphology. Edinburgh: Edinburgh University Press.

Bauer, L. 2004. "The borderline between derivation and compounding”. In: Dressler, W.U., D. Kastovsky, O.E. Pfeiffer and F. Rainer (eds.), Morphology and its demarcations. Selected papers from the 11th Morphology Meeting, Vienna, February 2004. Amsterdam/Philadelphia: John Benjamins. 97-108.

Bauer, L. 2014. “Concatenative derivation”. In: Lieber, R. and P. Štekauer (eds.), Derivational morphology. Oxford: Oxford University Press. 118-135.

Bauer, L., R. Lieber and I. Plag. 2013. The Oxford reference guide to English morphology. Oxford: Oxford University Press.

Booij, G. 2002. The morphology of Dutch. Oxford: Oxford University Press.

Booij, G. 2012. The grammar of words. An introduction to linguistic morphology. Oxford: Oxford University Press.

Booij, G. and M. Hüning. 2014. "Affixoids and constructional idioms”. In: Boogaart, R., T. Colleman and G. Rutten (eds.), Extending the scope of Construction Grammar. Berlin: De Gruyter Mouton. 77-106.

Donalies, E. 2000. "Das Konfix. Zur Definition einer zentralen Einheit der deutschen Wortbildung". Deutsche Sprache 28. 144-159.

Donalies, E. 2002. Die Wortbildung des Deutschen. Ein Überblick. Tübingen: Narr.

Elsen, H. 2005. "Deutsche Konfixe". Deutsche Sprache 33. 133-140.

Elsen, H. 2011. Grundzüge der Morphologie des Deutschen. Berlin: De Gruyter.

Hamans, C. 1988. "De overeenkomst tussen literama en actreutel. Zabrocki's diacrise als oplossing voor enige klassieke morfologische problemen”. Spektator 17. 289299.

Hamans, C. 1993. "Van epicentrum tot episch centrum: enige notities over distinctieve morfologie". Tabu 23. 63-73.

Hamans, C. 2010. "The productivity of blending: linguistic or cognitive? Or how to deal with administrivia and ostalgia”. In: Stanulewicz, D., T.Z. Wolański and J. Redzimska (eds.), Lingua Terra Cognita II. A Festschrift for professor Roman Kalisz. Gdańsk: Wydawnictwo Uniwersytetu Gdańskiego. 467-490.

Hamans, C. 2014. "What makes a blend - a reading report and some observations". In: Kleparski, G.A., E. Konieczna and B. Kopecka (eds.), Linguistics and methodology. (The Subcarpathian studies in English language, literature and culture. Vol. 1.) Rzeszów: Wydawnictwo Uniwersytetu Rzeszowskiego. 240-256.

Hamans, C. Submitted. "Between stub compounds and blends".

Hamans, C. Forthcoming. "The superiorty of the right part. About syllabic and prosodic characteristics of blends".

Hamans, C., J. Fisiak and E.H. Jahr. 2009. “Degrammaticalization and reanalysis". In: Łobacz, P., P. Nowak and W. Zabrocki (eds.), Language, science and culture. Essays in honor of Professor Jerzy Bańczerowski on the occasion of his 70th birthday Poznań: Wydawnictwo Naukowe UAM. 145-168. 
Haspelmath, M. 2004. "On directionality in language change with particular reference to grammaticalization". In: Fischer, O., M. Norde and H. Perridon (eds.), Up and down the cline - The nature of grammaticalization. Amsterdam/Philadelphia: John Benjamins. 17-44.

Heine, B., U. Claudi and F. Hünnemeyer. 1991. Grammaticalization: A conceptual framework. Cambridge: Cambridge University Press.

Hopper, P.J. and E. Closs Traugott. 1993. Grammaticalisation. Cambridge: Cambridge University Press.

Hüning, M. 1993. "Visies op taalverandering”. Forum der Letteren 34(4). 281-302.

Jespersen, O. 1928. A Modern English grammar on historical principles. (Part VI: Morphology.) London: Allen \& Unwin.

Keller, R. 1994. Sprachwandel. Tübingen: Francke.

Lass, R. 1990. "How to do with junk: Exaptation in language evolution". Journal of Linguistics 26(1). 79-102.

Lehmann, C. 1989. "Grammatikalisierung und Lexikalisierung". Zeitschrift für Phonetik, Sprachwissenschaft und Kommunikationsforschung 42. 11-19.

Lehrer, A. 1996. "Identifying and interpreting blends: An experimental approach". Cognitive Linguistics 7(4). 359-390.

Maiden, M. 2008. "Effects of word-formation processes in Italian. Reflections on Maria Grossmann and Franz Rainer (Eds) 2004. La formazione delle parole in italiano. Tübingen: Niemeyer". Rivista di Linguistica 20(2). 375-400.

Maciuszak, K. 2008. “The Persian suffix -(e)stan 'the land of"'. Studia Etymologica Cracoviensia 13. 119-140.

Marchand, H. 1969. The categories and types of Present-Day English word-formation. München: Beck.

Mattiello, E. 2013. Extragrammatical morphology in English. Abbreviations, blends, reduplicatives and related phenomena. Berlin/Boston: De Gruyter Mouton.

Mattiello, E. 2017. Analogy in word-formation. A study of English neologisms and occasionalisms. Berlin/Boston: De Gruyter Mouton.

Meesters, G. 2002. Marginale morfologie in het Nederlands: paradigmatische samenstellingen, neoklassieke composita en splintercomposita. (PhD dissertation, Katholieke Universiteit Leuven.)

Norde, M. 2006. "Van suffix tot telwoord tot bijwoord: Degrammaticalisering en (re)grammaticalisering van tig". Tabu 35. 33-60.

Norde, M. and K. Van Goethem. 2015. "Emancipatie van affixen en affixoïden: degrammaticalisatie of lexicalisatie?" Nederlandse Taalkunde 20. 109-148.

Olsen, S. 2014. "Delineating derivation and compounding". In: Lieber, R. and P. Štekauer (eds.), Derivational morphology. Oxford: Oxford University Press. 26-49.

Plag, I. 2003. Word-formation in English. Cambridge: Cambridge University Press.

Schmid, H.U. 1998. -lîh-Bildungen: Vergleichende Untersuchungen zu Herkunft, Entwicklung und Funktion eines althochdeutschen Suffixes. Göttingen: Vandenhoekc \& Ruprecht.

Ramat, P. 2001. “Degrammaticalization or transcategorization?” In: Schaner-Wolles, C., J. Rennison and F. Neubarth (eds.), Naturally! Linguistic studies in honour of Wolfgang Ulrich Dressler. Torino: Rosenberg and Sellier. 393-401. 
Schuchardt, H. 1922. In: Spitzer, L. (ed.), Hugo Schuchardt-Brevier. Halle: Max Niemeyer.

Van Goethem, K. 2008. “Oud-leerling versus ancient élève: A comparative study of adjectives grammaticalizing into prefixes in Dutch and French". Morphology 18(1). 27-49.

Van Goethem, K. and H. De Smet. 2014. "How nouns turn into adjectives. The emergence of new adjectives in French, English and Dutch through debonding processes". Languages in Contrast 14(2). 251-277.

Van den Toorn, M.C. 1983. "Morfeemsplinters". Gramma 7. 81-85.

Warren, B. 1990. "The importance of combining forms". In: Dressler, W.U., H.C. Luschützky, O.E. Pfeiffer and J.R. Rennison (eds.), Contemporary morphology. Berlin: Mouton de Gruyter. 111-132.

Zabrocki, L. 1969. "Phonologie und distinctive Morphologie". In: Graur, A. (ed.), Actes du Xe Congrès International des Linguistes Bucarest 1967. Bucarest: Editions de l'Académie de la République socialiste de Roumanie. 367-375. (Also in Zabrocki (1980). 105-112.)

Zabrocki, L. 1980. U podstaw struktury i rozwoju języka [At the foundation of language structure and development]. Warszawa/Poznań: Państowe Wydawnictwo Naukowe.

Zwicky, A. 2010. Libfixes. <http://arnoldzwicky.org/2010/01/23/libfixes/>

\section{Address for correspondence:}

Camiel Hamans

Dept. of General Linguistics

University of Amsterdam

c.s.j.m.hamans@uva.nl 